\title{
Study on the Countermeasure of the Construction of Dry Port in Jinan
}

\author{
Jianmeng Sun ${ }^{1, a^{*}}$, Haining Wang ${ }^{2, b}$ \\ ${ }^{1}$ Shandong Institute of Transportation Science, Jinan, Shandong 250023, China \\ ${ }^{2}$ Shandong Hi-speed Group Co., Ltd , Jinan, Shandong 250013, China \\ a*mxr6465201@126.comemail, b1767066139@qq.com
}

Keywords: Dry Port, Operation Mode, Countermeasures Study

\begin{abstract}
The development of dry port enhances the operation strength of the port, and the dry port can optimize the operation of the port and realize a series of functions of the port so as to relieve the operating pressure of the port. In the case of customs declaration, inspection and issuance of bill of lading, and transportation to port direct shipment, dry port can also reduce the retention of goods, improve the service level of the port and attract more customers. This article firstly analyzes the prospects of the development of Jinan inland dry port. Secondly, the operation model of dry port was studied in Jinan. Finally, the countermeasures on construction of dry port are put forward.
\end{abstract}

\section{Introduction}

The construction of dry port can drive the development of surrounding economic hinterland and solve some problems existing in the port. As an economic center, Jinan city has a relatively strong development strength, and Jinan has developed transportation, which provide favorable conditions for the development of dry port as a solid foundation. Jinan can extend the function of the port to inland areas by building a dry port inland. Although Jinan is not in the sea, the construction of the dry port can make Jinan fully use the advantages of the port. The construction of dry port expand the scope of Jinan foreign service, import and export enterprises so as to attract more investment in inland dry port, make dry port give full play to its geographical advantage and transportation advantage, reasonable use of the resources of Jinan inland, raise the level of economic development of Jinan inland.

\section{The Prospect Analysis of the Development of Inland Dry Port in Jinan}

\subsection{To Drive the Development of Surrounding Economy}

The construction of dry port will improve the consumption level of Jinan and drive the development of surrounding economy.The construction of dry port has great advantages in Jinan.Jinan traffic developed, can cooperate with multiple port direct connection.As the hinterland of multiple ports, Jinan provides goods for the transportation of the port, and provides necessary transportation facilities, manpower and material resources. The construction of dry port will not only drive the employment of Jinan to a certain extent, but also promote the development of transportation facilities, so that the economic strength will be further improved.The construction of dry port can promote the development of Jinan traffic facilities and to promote the tourism development of Jinan.

\subsection{To Be an Important Part of Port Logistics}

The construction of dry port in Jinan can promote the logistics development on inland region. It will promote the communication between Jinan and foreign countries.Customers can choose products that are more suitable for their products at home and abroad. The transportation, storage, packaging and information control of goods need advanced logistics technology.At the same time, the construction and use of dry port has brought new development to logistics technology and improved the service level of logistics. 


\subsection{To Promote Industrial Economic Development in Jinan}

The development of the inland dry port in Jinan is inseparable from the rapid development of Jinan's industrial economy. The development of industrial economy in Jinan in 2016 is shown in table 1.The industrial economic benefits have been further improved. In 2016, all the industrial benefits of Jinan have been improved, and the profits of visualization have been obtained. In 2016, the main business revenue of the above industries in Jinan was 572.26 billion yuan, up $7.3 \%$. The tax revenue was 72.76 billion yuan, up $7.7 \%$.The stronger industrial base promotes the increase of import and export goods.

Table1. Industrial Development in Jinan in 2016

\begin{tabular}{|c|c|c|}
\hline \multicolumn{2}{|c|}{ Unit: hundred million yuan } \\
\hline Industry & Profit & Up/down from last year \% \\
\hline Metal product industry & 44.4 & +13.6 \\
\hline Automobile industry & 30.2 & +68.7 \\
\hline $\begin{array}{c}\text { Chemical raw materials and chemical } \\
\text { products manufacturing }\end{array}$ & 22.9 & +17.4 \\
\hline $\begin{array}{c}\text { Petroleum processing, coking and nuclear } \\
\text { fuel processing }\end{array}$ & 16.7 & +114.1 \\
\hline
\end{tabular}

Source: Jinan statistical yearbook

\subsection{To Promote the Growth on Import and Export Trade in Jinan}

The development of inland dry port is inseparable from the growth of import and export trade in Jinan. The total import and export volume is shown in table 2 in 2016.

Table.2 Total Import and Export Volume of Enterprises in Jinan in 2016

Unit: \$100 million

\begin{tabular}{|c|c|c|}
\hline Enterprise property & Total volume of foreign trade & Year-on-year growth\% \\
\hline Private enterprise & 58.2 & 47.1 \\
\hline State-owned enterprise & 24.6 & -4.4 \\
\hline Foreign-invested enterprise & 23.1 & -26.6 \\
\hline Collectively-owned enterprise & 2.1 & -6.5 \\
\hline
\end{tabular}

The total volume of imports and exports in Jinan increased in 2016, mainly due to the increase in the import and export volume of private enterprises, while the number of other enterprises in the import and export volume decreased.If the construction on dry port inland in Jinan, which is mainly composed of international container transport mode will promote the foreign trade transportation, foreign trade transport will maintain the momentum of rapid growth in Jinan.

\section{Analysis of the Operation Mode of the Inland Dry Port in Jinan}

Jinan dry port can be used as a multiple port hinterland, increasing the dry port service range of ports. This will increase the dry port throughput, and to realize the collaborative development between ports, promote dry port and port of a win-win situation.

\subsection{The Operation Mode of Export on Dry Port}

The export process of the operation mode on dry port is shown in figure 1. 


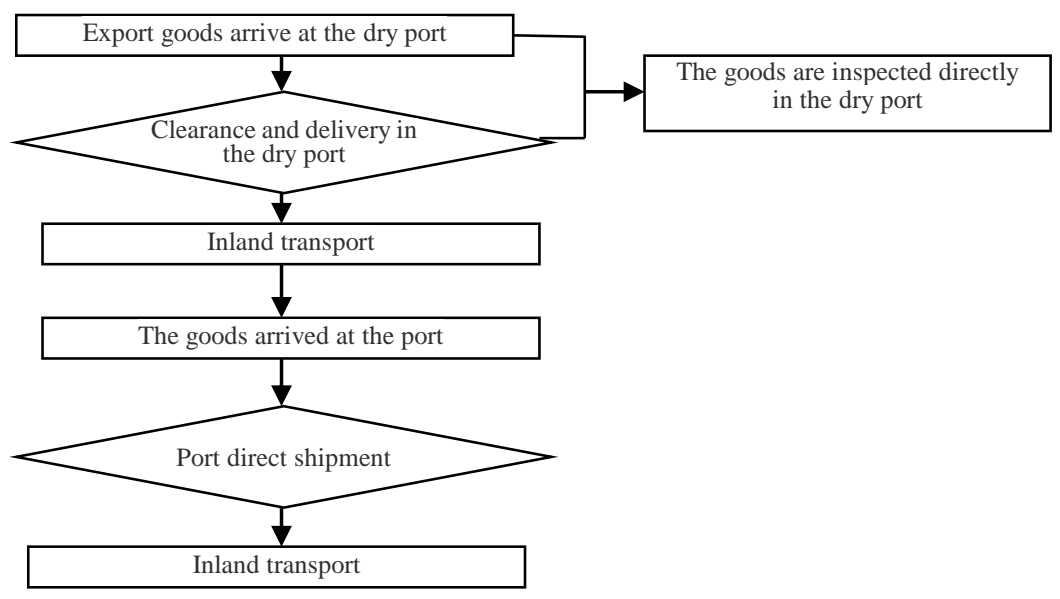

Figure.1 Export Operation Model of Dry Port

The shipper applies to the shipping company for the booking of the cabin, the production of documents, and customs clearance procedures at the port of dry port; The export goods will be transported to the dry port, and the information of the goods will be published on the port logistics information platform. Customs of dry port clearance procedures, and on the logistics information platform marked "handled" signs, at the same time electronic release information to the port customs; The customs shall, on the basis of the "handled" sign of dry port, handle the port release and send electronic release information to the port company;After receiving the box, the dock company will add the "to the port" sign on the logistics information platform; The dock company shall carry out the loading and loading operation according to the electronic release information;After the goods leave the port, there is dry to go through the customs formalities.

\subsection{The Operation Mode of Import on Dry Port}

The import process of the operation mode on dry port is shown in figure 2.

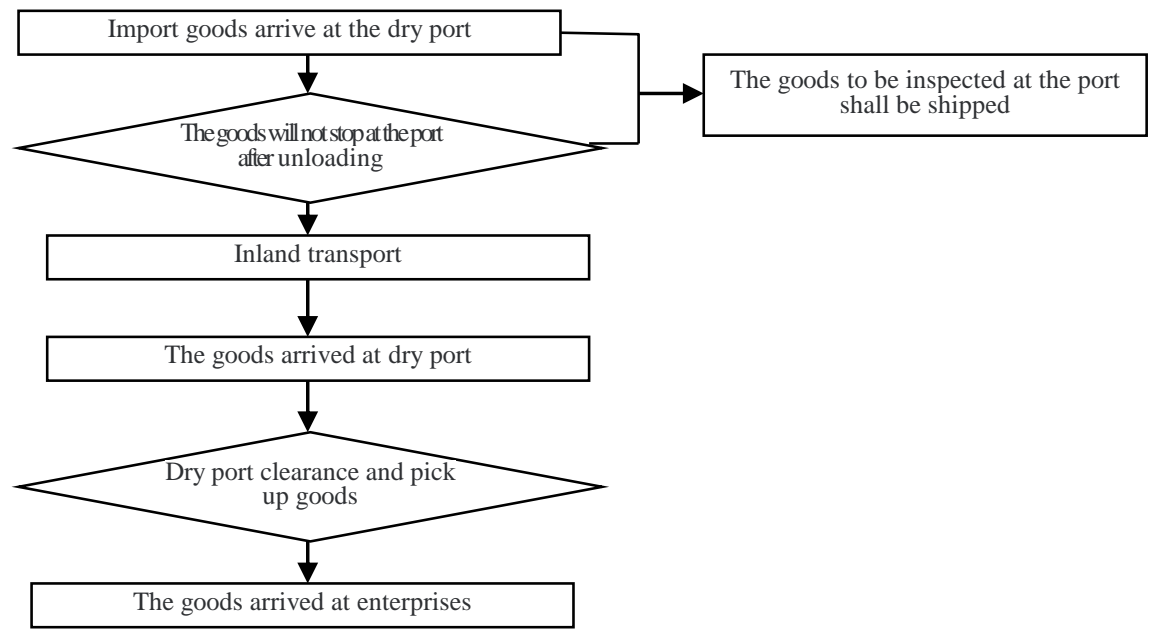

Figure.2 Import Operation Model of Dry Port

Before the ship arrives at the port, the transshipment manifest is transmitted to the port information platform and the inland dry port; Port customs approval and release on the logistics information platform; The inspection and quarantine department shall confirm whether to make inspection at the port according to the manifest of the information platform; The shipping company shall go to the dock to handle the formalities for handling the suitcase through the transfer manifest of the "shipping company transit release seal", and the dock shall examine the documents and the electronic information release goods; After the arrival of the goods at dry port, the shipper shall change the order in the dry port and send the electronic information to the dry port after the customs formalities are 
completed. The goods shall be released by the owner's documents and customs electronic information.

\section{The Countermeasure of the Construction of Inland Dry Port in Jinan}

\subsection{To Strengthen Cooperation with Neighboring Ports}

Jinan strengthens cooperation with Tianjin, Qingdao, Rizhao,Weihai, Yantai and so on.The location of Jinan is superior, and the transportation modes connected with Tianjin, Qingdao, Rizhao, Weihai and Yantai are quite developed.Jinan can serve as the economic hinterland of these ports, and there is a good source of goods for the construction of dry port in Jinan.Jinan in Shandong province as the market economy, is connected to the junction of north and south China, and other places of goods transport can adopt the method of rail and road transport, and port of collaboration can make use of railway, highway, waterway transport methods.Jinan should strengthen regional cooperation with ports and actively expand the economic hinterland of landless port.

\subsection{To Actively Develop the Port-surrounding Industry}

Jinan dry port should actively promote the interior supply, can also according to the requirement of the port, vigorously develop port-vicinity industry, promote the development of port and economic hinterland, realize win-win situation of port and city hinterland. The port industry can also increase the employment in the economic hinterland, improve the industrial structure of the economic hinterland, optimize the industrial chain of the economic hinterland, and speed up the development of the dry port in Jinan.

\subsection{To Accelerate the Construction of Corridor on Logistics}

We will speed up the construction of internal and external highway corridors to further improve the existing highway channel levels. We will build a special transport network system for passenger and cargo distribution, further strengthen the docking of the ports and inland hinterland highways, and improve the efficiency of highway collection and transportation. we should speed up the planning and construction of special railway transportation channels, and give full play to the advantages of the railway transportation demonstration project.

\subsection{To Timely Adjust the Strategy and Innovate Idea}

The development of dry port in Jinan needs to deal with the dynamic changes, and timely adjust the strategy of the development of the dry port, so as to realize the combination of the development strategy and the development of dry port. The development concept of dry port needs to be innovated. We will promote the system innovation of dry port, improve the management level of the dry port, and realize the synchronization of innovation and actual situation.

\section{Summary}

The construction of dry port will increase the freight volume of the coastal port, expand the hinterland of the port and improve the convenience of inland foreign logistics, which is the development direction of the domestic and foreign port service network. The construction of dry port is of great significance to the development of the current logistics industry. For the port, the inland hinterland can reduce the accumulation and retention of port goods, which can improve the operation efficiency of the port. As a bridge connecting the outside world, dry port has great effect on inland economic development. According to the experience of domestic and foreign dry, the construction and operation of dry port may be extended to many cities. This paper puts forward the model and construction countermeasure of Jinan dry port. 


\section{References}

[1] Mr.John Edward,Logistics Outsourcing,Inbound Logistic,January,2006.

[2] Kijkam. Comparative modeling of interregional transport flows:Applieation Stomulti modal European freight transport t[M].London: Maemi11an, 1995.

[3] Ballis.A.,Golias.J.,Comparative Evaluation of Existing and Innovative Rail Road Freight Transport Terminals,Transportation Research,2002,36 : 593-611.nagement: a state-ofthe-art literature review. International Journal of Management Reviews 2007;9(1):53-80

[4] Woxenius, J.,Roso.V.,The Dry Port Concept Connecting Seaports with Hinterland by Rail,the ICLSP Conference, China,Dalian,September,2004:22-26. 